\title{
Essay
}

\section{The Anti-Antidiscrimination Agenda}

\author{
Jed Rubenfeld ${ }^{\dagger}$
}

People are pretty sure there is something going on in constitutional law these days, but they don't know what it is.

Since about 1995, the Supreme Court has issued groundbreaking decisions on so many subjects-for example, the commerce power, affirmative action, the Eleventh Amendment, Section 5 of the Fourteenth Amendment, and expressive association-that observers are beginning to step back from the various doctrinal debates to see if a bigger picture is emerging. One recent symposium asked whether constitutional law was undergoing a "sea change," as opposed to minor modifications in disparate areas. 'Those who sympathize with the Court's decisions have seen a new "textualism" at work $;^{2}$ critics have claimed, on the contrary, that a new "judicial activism," especially in the area of federalism, can be seen below the recent tectonic shifts. ${ }^{3}$

But the epithet "activism" is just a colorful way of disagreeing, and both the "textualism" and "federalism" tags are manifestly insufficient. Take Boy Scouts of America v. Dale, ${ }^{4}$ in which the Court held that the Scouts had a constitutional right to expel a scoutmaster because of his homosexuality. The right at issue, the Court held, was the "First

$\dagger$ Slaughter Professor of Law, Yale Law School.

1. Symposium, The Constitution in Exile, 51 DUKE L.J. 1 (2001).

2. See, e.g., Steven G. Calabresi, Textualism and the Countermajoritarian Difficulty, 66 GEO. WASH. L. REV. 1373, 1389-90 (1998). For Justice Scalia's defense of textualism, see ANTONIN SCALIA, A MATTER OF INTERPRETATION 47 (1997).

3. See, e.g., Scott Fruebwald, If Men Were Angels: The New Judicial Activism in Theory and Practice, 83 MARQ. L. REV. 435 (1999); Donald H. Zeigler, The New Activist Court, 45 AM. U. L. REV. 1367 (1996); Larry D. Kramer, Editorial, No Surprise. It's an Activist Court, N.Y. TIMES, Dec. 12, 2000, at A33.

4. 530 U.S. $640(2000)$. 
Amendment's expressive associational right," ${ }^{5}$ but of course the First Amendment does not enumerate any freedom of association (this right being effectively a creation of Warren Court cases ${ }^{6}$ ), so Boy Scouts cannot remotely be explained as a "textualist" decision. Moreover, Boy Scouts involved a state law, so the case is antifederalist as well. The fact is that the Court has been by turns textualist and antitextualist, federalist and antifederalist, in its pathbreaking decisions-a fact that itself encourages one to step back from the compartmentalized doctrinal wrangling to try to get a larger picture.

In place of judicial activism, textualism, or federalism, I want to suggest a different unifying thread behind the Court's innovative constitutional case law. I offer this suggestion in an exploratory vein. It is possible that an anti-antidiscrimination agenda, deeply felt but as yet poorly theorized, is working itself out in the current Court's jurisprudence.

What is an anti-antidiscrimination agenda? Imagine someone who believed that the "liberal" antidiscrimination movement had taken off in a direction threatening fundamental American values and freedoms. These perceived threats would include: the erosion of meritocracy, the creation of a sense of entitlement among undeserving people, the insistence that homosexuality be protected instead of condemned, the fomenting of a victimization culture, and so on. A person who held this view might say the following:

Of course discrimination is bad. But liberals and minorities have gone too far. If you oppose homosexuality, you're "discriminating." If you don't pay hundreds of thousands of dollars to make readers available for blind people who want to be lawyers, you're "discriminating." Domestic violence is supposed to be "sexual discrimination." Don't get me wrong: Domestic violence is bad, but calling it "sexual discrimination" is ridiculous. And the most ridiculous thing of all is "affirmative action," which is discrimination, but which they say we have to have to "promote diversity."

These points line up in an interesting way with a series of the most important and most novel decisions handed down by the Supreme Court in recent years. In Boy Scouts, as just noted, the Court held that associations have a right to exclude homosexuals. In Garrett ${ }^{7}$ and Morrison, ${ }^{8}$ the Court held that the Americans with Disabilities Act and the Violence Against Women Act, respectively, did not "enforce" the Equal Protection Clause's

5. Id. at 648.

6. See, e.g., NAACP v. Alabama, 357 U.S. 449 (1958).

7. Bd. of Trs. of the Univ. of Ala. v. Garrett, 531 U.S. 356 (2001).

8. United States v. Morrison, 529 U.S. 598 (2000). 
antidiscrimination guarantee and hence exceeded Congress's power under Section 5 of the Fourteenth Amendment. In Adarand, ${ }^{9}$ the Court held that governmental affirmative action measures are subject to the nearly-alwaysfatal strict scrutiny standard of review. And this is only a partial list.

The anti-antidiscrimination view need not openly contest "traditional" antidiscrimination law. It can embrace the idea that everyone should have equal opportunities regardless of race, sex, creed, or color. But it is hostile to the more "radical" extensions of antidiscrimination law, especially those that seek to protect traditionally unprotected groups, extend antidiscrimination ideas to unusual contexts, or push the law beyond the principle of formal legal equality.

Assume that five members of the Supreme Court hold the antiantidiscrimination view. They would then believe that antidiscrimination law today (not in its traditional form, but in its excesses) poses serious threats to American values and freedoms. Their difficulty, however, would be that there is as yet no clear theory explaining why "traditional" antidiscrimination law is justifiable and constitutional, while the extensions of antidiscrimination law are not. The result could be an antiantidiscrimination agenda: an effort, sometimes overt but sometimes covert as well, to find constitutional grounds for invalidating laws perceived to take antidiscrimination ideology too far.

Not all, but a good deal of the present Supreme Court's groundbreaking constitutional case law makes better sense when viewed not in the doctrinal terms in which it presents itself, but in terms of an anti-antidiscrimination agenda of this kind. This is so not only in cases explicitly dealing with discrimination under the Equal Protection Clause-such as the affirmative action cases-but also in other cases from far-flung, seemingly unrelated constitutional fields, including the Commerce Clause, the First Amendment (religion and speech), the Eleventh Amendment, and Section 5 of the Fourteenth Amendment. Several of the Court's decisions in these areas are so difficult to take seriously in their own doctrinal terms, I argue, that the anti-antidiscrimination agenda offers a much more credible explanation of them.

If all this is true, it would not follow that the Supreme Court's new case law is wrong. Someone might say, on the contrary, that the antiantidiscrimination view is right, and that the Court's real task is to theorize this view more articulately, so that it can stand on its own constitutional footing, rather than disguising itself behind such stalking-horses as federalism, freedom of speech, or the Eleventh Amendment. On this question, I will have nothing to say.

9. Adarand Constructors, Inc. v. Pena, 515 U.S. 200 (1995). 
What I will try to show, however, is that the Eleventh Amendment, federalism, and freedom of speech are in fact stalking-horses in the Court's new constitutional case law. In other words, I will try to show, for example, that some of the Court's federalism cases are not really federalism cases at all-that they cannot be intelligently explained or debated in the doctrinal terms in which they present themselves. This is a difficult showing to make, but an important one, if the idea of an unacknowledged antiantidiscrimination agenda driving these cases is to have its strongest purchase.

Part I of this Essay explains how I try to make this showing. One way to suggest that certain members of the Supreme Court are deeply but perhaps covertly hostile to antidiscrimination law is to rely on biographical or personal information about them, such as stories alleging that Chief Justice Rehnquist participated as a young political operative in efforts to stop blacks from voting, ${ }^{10}$ or certain crude psychoanalyses of Justice Thomas. ${ }^{11}$ I expressly disclaim this kind of argument, which, whatever its merits for other purposes, is unreliable and unproductive for the law.

Instead, I pursue a kind of analysis that might be called juxtaposition across doctrines. This simply means asking how decisions from one doctrinal category relate to those from others. Unsurprisingly, given lawyers' basic training in doctrinal sorting, the relationships among different doctrines are systemically underappreciated in the legal literature. A line of cases can seem perfectly intelligible when evaluated in its own doctrinal compartment, yet its intelligibility can evaporate altogether when placed side by side with another line of cases. This is so, I argue, with respect to a good deal of the Court's "federalism" case law. Part I explains this juxtapositional method and begins its application with a discussion of the Court's recent Eleventh Amendment cases.

Part II then takes up the Court's Commerce Clause and Section 5 cases and juxtaposes them with the Boy Scouts decision. Through this juxtaposition, I hope to show that some of the Court's most important new pronouncements in constitutional law cannot be taken seriously in their own doctrinal terms, but are better understood as part of an antiantidiscrimination agenda. Part II attempts to make the same showing in connection with the Court's affirmative action cases.

10. See, e.g., Rehnquist and Minority Voters, NATION, Jan. 1, 2001, at 7.

11. See, e.g., Charles R. Lawrence III \& Mari J. Matsuda, We Won't Go Back 139 (1997) (asserting that Justice Thomas may suffer from "internalized racism and selfdeprecation"). 


\section{JUXTAPOSITION AND THE FEDERALISM TRAP}

There is a particular doctrinal trap that renders constitutional decisions impossible to take seriously in the legal terms in which they present themselves. It has to do with federalism. Constitutional law has fallen into this trap before. The question is whether it has done so again today.

Seeing this trap requires undertaking the kind of analysis mentioned above: juxtaposition across doctrines. Lawyers are trained to assimilate cases by separating them into more or less distinct lines of doctrine. The virtues of doctrinal sorting are obvious. Without it, the legal system could not possibly digest tens of thousands of cases, nor could individuals develop expertise in particular fields. But this practice obviously inhibits vision too, as do the blinders on a horse. While directing and focusing attention, it also tends to suppress appreciation of how differing lines of case law relate to one another. By failing to see these interdoctrinal relationships, we can be misled into taking cases seriously long after they have stopped making sense.

As most people know by now, five Justices of the Supreme Court are beginning to rewrite the map of American federalism. The decisive stroke came in 1995 when the Court struck down a federal "gun-free school zones" statute on the ground that it exceeded the reach of the commerce power. ${ }^{12}$ In some quarters, the new federalism decisions have provoked a reaction close to outrage, as if unlimited federal legislative jurisdiction were an unwritten constitutional right. For myself, the thought that the Commerce Clause might actually mean something does not seem exactly shocking.

But to take the present majority's federalism cases seriously, to defend or to criticize them in the doctrinal terms in which they present themselves, demands that we see them a certain way-namely, as federalism cases. To see federalism cases as federalism cases will not strike most readers as wildly misguided. Sometimes, however, a decision can sound like a federalism case, and be received and debated as a federalism case, without actually being a federalism case at all.

12. United States v. Lopez, 514 U.S. 549 (1995). While Lopez is often said to represent "the first time in nearly sixty years" in which the Court "invalidated . . . a congressional reliance on its commerce power," GERALD GUNTHER \& KATHLEEN M. SUlLIVAN, CONSTITUTIONAL LAW 142 (13th ed. 1997), the honor actually seems to belong to New York v. United States, 505 U.S. 144 (1992), which struck down a federal hazardous waste disposal statute in part on the ground that the Commerce Clause "authorizes Congress to regulate interstate commerce" and not to "regulate state governments' regulation of interstate commerce." $I d$. at 166. 


\section{A. Pseudo-Federalism}

The landmark "federalism" decisions of the Lochner era provide the clearest examples. In these cases, the Supreme Court struck down important federal economic measures on the ground that Congress had exceeded its Commerce Clause authority. ${ }^{13}$ According to the logic of these "federalism" decisions, the pertinent regulatory power-the power to regulate the activity at issue-did not lie with Congress, but was constitutionally reserved to the states. The embarrassment was that when state governments passed very similar regulatory measures, the Lochner Court would strike down these measures too, this time on the basis of an unwritten "liberty of contract" derived from an oxymoronic "substantive due process." "14

We have been smiling at this for decades. The Court's "liberty of contract" doctrine did not, strictly speaking, contradict the Court's Commerce Clause doctrine. But the happy coincidence-i.e., the felicitous congruence of results, under which unwritten constitutional law just happened to pop up and prevent states from doing exactly what the Commerce Clause allegedly prevented Congress from doing on "textualist," "federalist" grounds-tells the story. The Lochner era's "federalism" was not really about federalism at all. It was a kind of doctrinal joke.

The joke could easily have been missed at the time. Considered on their own, the Lochner "federalism" cases looked perfectly intelligible. They could be debated and defended just as if they really offered a serious effort to grapple with the problems of allocating power between the federal and state governments under the specific textual grants and reservations of power laid out in the Constitution.

Unfortunately, those who tried to understand the Lochner-era case law this way turned out to be engaged in a bootless, credulous enterprise. The constitutional case law of the Lochner era could not, in reality, be understood in the doctrinal terms in which it presented itself. Those who tried to make sense of it in doctrinal pieces were victims of a kind of charade. The Lochner case law made sense only as a whole - and made sense only in the sense that, taken as a whole, the cases revealed the laissez-

13. E.g., Carter v. Carter Coal Co., 298 U.S. 238 (1936); R.R. Ret. Bd. v. Alton R.R. Co., 295 U.S. $330(1935)$.

14. For example, in A.L.A. Schechter Poultry Corp. v. United States, 295 U.S. 495 (1935), the Court invalidated a federal code establishing a forty-hour work week and a minimum wage for some workers. But as everyone knows, the definitive decisions of the Lochner era held that states could not pass maximum-hour or minimum-wage laws. E.g., Adkins v. Children's Hosp., 261 U.S. 525 (1923) (minimum wage); Lochner v. New York, 198 U.S. 45 (1905) (maximum hours). 
faire, antiredistributive agenda that was driving them, quite apart from any considerations of constitutional language, history, doctrine, or principle. ${ }^{15}$

In this light, reconsider the present Court's new case law concerning the Commerce Clause and Section 5 of the Fourteenth Amendment. ${ }^{16}$ This case law appears to take the problems of federalism very seriously, and it appears to do so, moreover, with the utmost respect for the strict limits of the Constitution's text. ${ }^{17}$ Once again, legal professionals, both practitioners and academics, dutifully slot the decided cases into their respective doctrinal boxes, analyzing, synthesizing, and arguing about them accordingly. ${ }^{18}$

But at the same time, we are also analyzing, in different doctrinal boxes, other lines of decisions whose relationship to these "federalism" cases ought to strike us as a little puzzling. For example, even as we debate the merits of the five Justices' ostensibly textualist federalism cases, we are also debating their astonishing Eleventh Amendment doctrine, in which unwritten constitutional law fortuitously pops up as a seamless supplement to their Commerce Clause holdings. Then there is the Court's bold new freedom of association holding, in which unwritten constitutional law pops up again, this time preventing states from doing something very similar to what they have said, in their "federalism" decisions, that Congress cannot do without entrenching on state prerogatives.

When we juxtapose these different lines of case law, certain gross coincidences and equally gross disparities become hard to ignore. The coincidences have to do with the outcomes; the disparities have to do with the underlying logic and methodology. As in the Lochner era, the Court's repeated reliance on unwritten constitutional law-both to further its ostensibly textualist "federalism" when federal law is at issue and, more significantly, to block states from passing laws that, according to the "federalism" decisions, ought to be core exercises of state legislative

15. The most remarkable single illustration of this agenda and of the illusory nature of the Court's doctrinal manipulations is probably Coronado Coal Co. v. United Mine Workers, 268 U.S. 295 (1925), where, contrary to what the Court was then saying with respect to both the Commerce Clause and the "liberty of contract," the Court upheld the application of the Sherman Act against striking mine workers.

16. See, e.g., United States v. Morrison, 529 U.S. 598 (2000) (striking down portions of the Violence Against Women Act); City of Boeme v. Flores, 521 U.S. 507 (1997) (striking down the Religious Freedom Restoration Act).

17. See, e.g., Morrison, 529 U.S. at 613 (emphasizing that gender-based violence is not "commercial" in nature); Boerne, 521 U.S. at 519 (strictly construing the word "enforce" in Section 5 of the Fourteenth Amendment).

18. See, e.g., Larry D. Kramer, But When Exactly Was Judicially-Enforced Federalism "Born" in the First Place?, 22 HARV. J.L. \& PUB. POL'Y 123 (1998); Larry D. Kramer, Putting the Politics Back into the Political Safeguards of Federalism, 100 ColUM. L. REV. 215 (2000); Robert C. Post \& Reva B. Siegel, Equal Protection by Law: Federal Antidiscrimination Legislation After Morrison and Kimel, 110 YALE L.J. 441 (2000); Donald H. Regan, How To Think About the Federal Commerce Power and Incidentally Rewrite United States v. Lopez, 94 MiCH. L. REV. 554 (1995). 
power-tells a story very different from the official accounts being debated in the piecemeal doctrinal literatures. This is the doctrinal trap I referred to above.

\section{B. The Eleventh Amendment}

The best place to start is with the recent "federalism" decision of University of Alabama v. Garrett. ${ }^{19}$ The facts of this case were simple. Patricia Garrett worked as Director of Nursing for a state university. After undergoing surgery for breast cancer, she was demoted to a lower-paying job as a nurse manager. She sued the university under the Americans with Disabilities Act (ADA), which prohibits employers, both governmental and private, from discriminating against disabled people. Garrett sought money damages, alleging that the University of Alabama demoted her not because of a genuine inability to perform her job, but because of her illness and treatment. ${ }^{20}$

The Supreme Court rendered a 5-4 decision. The split among the Justices followed a familiar pattern, with Chief Justice Rehnquist joined in the majority by Justices O'Connor, Scalia, Kennedy, and Thomas. ${ }^{21}$ These five Justices dismissed the case under the Eleventh Amendment. Garrett thereby joined a string of recent decisions that have given the Eleventh Amendment new constitutional bite ${ }^{22}$ and that fit very comfortably with many of the Court's other decisions curbing congressional authority vis-àvis the states.

The Eleventh Amendment bars federal court jurisdiction of certain suits brought against a state. ${ }^{23}$ Congress, however, has the power to override the Eleventh Amendment under Section 5 of the Fourteenth Amendment, which empowers Congress to pass "appropriate legislation" to "enforce" the Equal Protection Clause and the Fourteenth Amendment's other provisions. ${ }^{24}$ As a result, the question in Garrett was whether the ADA fell within Congress's Section 5 powers. The Court's answer was no. ${ }^{25}$ Hence the Eleventh Amendment was controlling, and it barred Garrett's suit.

19. Bd. of Trs. of the Univ. of Ala. v. Garrett, 531 U.S. 356 (2001).

20. Id. at 362 .

21. Id. at 358 .

22. See, e.g., Kimel v. Fla. Bd. of Regents, 528 U.S. 62, $72-73$ (2000); Coll, Sav. Bank v. Fla. Prepaid Postsecondary Educ. Expense Bd., 527 U.S. 666, 675-87 (1999); Seminole Tribe v. Florida, 517 U.S. 44, 54-55 (1996).

23. U.S. ConsT. amend. XI ("The Judicial power of the United States shall not be construed to extend to any suit ... commenced ... against one of the United States by Citizens of another State, or by ... Subjects of any Foreign State.").

24. U.S. CoNST. amend. XIV, \& 5; see Fitzpatrick v. Bitzer, 427 U.S. 445,456 (1976) (holding that the Eleventh Amendment is "necessarily limited by the enforcement provisions of $\S 5$ of the Fourteenth Amendment").

25. Garrett, 531 U.S. at 360. 
Taken seriously as Eleventh Amendment doctrine, Garrett raises deep and potentially disturbing questions of constitutional principle. With Garrett and its predecessor cases, the present Court has created a doctrinal structure that is, in a way, very odd. The key to understanding this doctrinal structure is to see that the Garrett majority did not hold the ADA unconstitutional, not even as applied to state employers. Although the five Justices found that the ADA was not a valid piece of Section 5 legislation, the ADA remains perfectly valid under the Commerce Clause, even insofar as it regulates the conduct of state employers. ${ }^{26}$ In other words, the ADA's prohibitions of discrimination against disabled people remain completely binding on state employers (under the Commerce Clause), and the Court assumed, for purposes of the decision, that Alabama had violated Garrett's statutorily mandated legal rights. ${ }^{27}$ The five Justices' holding was "merely" that Garrett was barred from enforcing these rights by the Eleventh Amendment.

It is important to get a firm grip on what this means. Suppose that, just because she lost a breast to cancer, Alabama decided to pay Garrett only half her salary, even though she did all her work and did it as competently as every other employee in her position. Alabama would have broken the law. There would be no dispute about Garrett's legal rights. Under the ADA, Garrett would be legally entitled to the money she ought to have been paid.

Under Garrett, however, she could not collect it. She would be legally entitled to the money under federal law, but the federal courts would be barred to her. (State courts would also be closed to her under state-law doctrines of sovereign immunity. ${ }^{28}$ She has a legal right, but she has no legal right.

Most people know the case that principally inaugurated constitutional law in America. It was Marbury v. Madison. ${ }^{29}$ In that case, Chief Justice Marshall said: "The very essence of civil liberty certainly consists in the right of every individual to claim the protection of the laws, whenever he receives an injury." ${ }^{30}$ Or again: "The government of the United States has been emphatically termed a government of laws, and not of men. It will certainly cease to deserve this high appellation, if the laws furnish no

26. See id. at $374 \mathrm{n.9}$ ("Title I of the ADA still prescribes standards applicable to the States.").

27. Garrett came to the Supreme Court on appeal from an order granting summary judgment to the University of Alabama, id. at 362-63, so Garrett's allegations were assumed true for purposes of the decision.

28. See, e.g., Larkins v. Dep't of Mental Health \& Mental Retardation, No. 1991538, 2001 WL 632948 (Ala. June 8, 2001) (dismissing on sovereign immunity grounds an employee's suit against a state employer alleging violations of a federal statute).

29. 5 U.S. (1 Cranch) 137 (1803).

30. Id. at 163 . 
remedy for the violation of a vested legal right." ${ }^{31}$ Or again: "[W]here a specific duty is assigned by law, and individual rights depend upon the performance of that duty, ... the individual who considers himself injured, has a right to resort to the laws of his country for a remedy." 32

So the first thing to observe about the Court's new Eleventh Amendment case law is that it leaves a dent-some would say a gouge-in the heart of a constitutional principle of very long standing. To be sure, Garrett did not leave Garrett wholly without remedy. As the majority pointed out in a helpful footnote, the United States government always has the constitutional power to sue states. ${ }^{33}$ Why? Because the federal government is not covered by the Eleventh Amendment, which bars suits against states only by "Citizens of another State" and by "Citizens or Subjects of any Foreign State." ${ }^{34}$ Thus there remains a jurisdictional possibility that the United States might sue Alabama on Garrett's behalf and then remit the damages to Garrett.

But the United States is not obliged to do that. The remarkable fact remains that, despite Marbury and dozens of other cases reaffirming its principle, disabled people in Garrett's situation, whose individual rights are by hypothesis incontrovertibly violated, do not have "a right to resort to the laws of [their] country for a remedy." ${ }^{35}$ It is as if under Garrett, disabled people who suffer monetary damage because of discrimination by a state employer are living in a classical international law regime, where individuals have no legal standing in their own person, and a seeming violation of their legal rights is not a violation of their legal rights after all, but at best a violation of the rights of their national government, which may or may not, depending on political factors and resource constraints, choose to bring a claim on their behalf before an international tribunal (formerly known as federal court).

Everything I have said to this point remains firmly within the conventional debate about whether Garrett is right or wrong as a matter of Eleventh Amendment doctrine. And nothing I have said demonstrates that Garrett is a legally indefensible Eleventh Amendment result. As readers might imagine, Garrett and its predecessor cases have prompted a plentiful debate in the academic journals retelling the history of the Eleventh Amendment, analyzing its intricate interplay with Section 5 of the Fourteenth Amendment, and revisiting the constitutional status of

31. Id.

32. Id. at 166.

33. See Garrett, 531 U.S. at 374 n.9.

34. U.S. CONST. amend. XI.

35. Marbury, 5 U.S. (1 Cranch) at 166. 
Marbury's "for every individual right, an individual remedy" principle, which once seemed untouchable. ${ }^{36}$

But the point of this Essay is not to pursue that debate. On the contrary, the question is whether it makes sense to have this sort of debate-the kind that takes the Court's new case law seriously. To begin to see why it might not make sense, readers need to know a little more about the oddness of the Court's new Eleventh Amendment case law. As noted, the Eleventh Amendment bars federal court jurisdiction over suits against a state brought by "Citizens of another State." Readers who knew this much about the Eleventh Amendment, but were unfamiliar with the facts of Garrett, might well have assumed that Garrett was a citizen of some state other than Alabama. Not at all. Garrett was an Alabama resident. ${ }^{37}$ She was a citizen of the same state she was suing.

In other words, to reach the desired result, the five Justices in Garrett had to do more than dent a principle established in Marbury v. Madison. They had to read "another" to mean "the same." In case anyone has not noticed, these two terms are antonyms.

Once upon a time, judicial conservatives criticized those who saw in the Constitution words that were not there, like "privacy." Garrett goes one better. Garrett reads a word that is in the Constitution to mean its opposite.

A useful comparative exercise might be to imagine the Court holding, in a double jeopardy case, that "the same offense" also included "another offense," so that nobody convicted of one crime could ever be prosecuted again. ${ }^{38}$ Another useful exercise would be to imagine that holding again (by "another" in this sentence, I mean "the same"). Or how about a case holding that the Eleventh Amendment's ban on federal court jurisdiction meant a ban on state court jurisdiction too? Surely if the Court began to play that kind of trick with the Eleventh Amendment, people would have to acknowledge that we were no longer dealing, in any serious way, with an "Eleventh Amendment doctrine" at all. (A note for the noncognoscenti: The Court already has "extended" the Eleventh Amendment to cover state court jurisdiction.) ${ }^{39}$

36. See, e.g., Vicki C. Jackson, Coeur d'Alene, Federal Courts and the Supremacy of Federal Law: The Competing Paradigms of Chief Justices Marshall and Rehnquist, 15 CONST. COMMENT. 301 (1998); Carlos Manuel Vázquez, What Is Eleventh Amendment Immunity?, 106 YALE L.J. 1683 (1997); Lauren Ouziel, Note, Waiving States' Sovereign Immunity from Suit in Their Own Courts: Purchased Waiver and the Clear Statement Rule, 99 COLUM. L. REv. 1584 (1999).

37. See Gartet v. Bd. of Trs. of the Univ. of Ala., 989 F. Supp. 1409 (N.D. Ala. 1998), rev'd, 193 F.3d 1214 (11th Cir. 1999), rev'd, 531 U.S. 356 (2001).

38. The Fifth Amendment provides that no person "shall . . be subject for the same offence to be twice put in jeopardy of life or limb." U.S. CONST. amend. V.

39. Alden v. Maine, 527 U.S. 706 (1999). 
There is a single sentence in the Garrett majority opinion devoted to the same/other problem: "Although by its terms the [Eleventh] Amendment applies only to suits against a State by citizens of another State, our cases have extended the Amendment's applicability to suits by citizens against their own States." 40 This sentence strangely echoes Justice Brandeis's famous statement seventy-five years ago that although the Due Process Clause appeared to apply only to "matters of procedure," case law had established the existence of substantive due process as well." (The difference is that the Garrett majority intends no irony.) The string of precedents offered by the five Justices in support of their proposition-with the exception of a 100-year-old case dubious in its logic and authorityconsists entirely of recent decisions. ${ }^{42}$

The Court's new Eleventh Amendment decisions represent, at best, pure unwritten constitutional law. It is impossible to take seriously, as an act of interpretation, a construction of the word "same" to mean "another," or a construction of "federal" court jurisdiction to refer to "state" court jurisdiction. Can anyone believe that it is merely a coincidence that this unwritten constitutional law happens to mesh seamlessly with the Court's ostensibly textually based "federalism" doctrines?

If a certain suspicion is raised here-a suspicion not of bad faith, but of the possibility that the Court's "Eleventh Amendment" doctrine cannot be profitably understood as Eleventh Amendment doctrine-the next question becomes whether the Court's "federalism" holdings can be taken any more seriously than the "Eleventh Amendment" doctrine that furthers this "federalism." On this question, it is critical to examine the new case law restricting state power.

\section{FEDERALISM AND THE FREEDOM OF ASSOCIATION}

In a bold and potentially extremely important recent opinion, the Supreme Court $\rightarrow$ or rather five members of the Supreme Court, the same five listed above - concluded that New Jersey could not constitutionally bar the Boy Scouts from expelling a scoutmaster on the basis of his homosexuality ${ }^{43}$ What constitutional provision did New Jersey violate when it tried to stop the Boy Scouts from discriminating on the basis of

40. Garrett, 531 U.S. at 363.

41. Whitney v. California, 274 U.S. 357, 373 (1927) (Brandeis, J., concurring) ("Despite arguments to the contrary which had seemed to me persuasive, it is settled that the due process clause of the Fourteenth Amendment applies to matters of substantive law as well as to matters of procedure.").

42. See Kimel v. Fla. Bd. of Regents, 528 U.S. 62, $72-73$ (2000); Coll. Sav. Bank v. Fla. Prepaid Postsecondary Educ. Expense Bd., 527 U.S. 666, 669-70 (1999); Seminole Tribe v. Florida, 517 U.S. 44, 54 (1996); Hans v. Louisiana, 134 U.S. 1, 15 (1890).

43. Boy Scouts of Am. v. Dale, 530 U.S. 640 (2000). 
sexual orientation? According to the majority in Boy Scouts v. Dale, the answer was the First Amendment. The majority ruled that New Jersey's statute impermissibly intruded upon the Scouts" "First Amendment[] protection of expressive association." 44

Predictably, Boy Scouts has already generated considerable debate. ${ }^{45}$ This debate is natural. I have contributed to it myself. ${ }^{46}$ Here, however, the goal is to bracket this debate, in order to ask whether it makes sense to take Boy Scouts seriously as a "First Amendment" case at all. Could "freedom of expressive association" be the present Court's "liberty of contract"i.e., the unwritten constitutional right that felicitously pops up to prevent states from doing exactly what the Court has been supposedly telling us, in its "federalism" cases, that Congress cannot do without usurping state authority?

\section{A. Elements of the Federalism Trap}

Thinking through this possibility requires that we first identify more carefully the elements of the simple but suspect doctrinal trap that, as noted earlier, obtained during the Lochner era due to the coexistence of the Lochner Court's Commerce Clause and "liberty of contract" holdings. Once we identify the pieces of this suspect doctrinal configuration, the question will be to what extent the same configuration can be seen in the juxtaposition of the present Court's "federalism" decisions and its freedom of association holding in Boy Scouts v. Dale.

Described most starkly, the suspect doctrinal configuration would comprise the following two lines of cases. Start with a set of selfprofessedly "textualist" "federalism" cases. These cases, which involve federal statutes, must display a strict respect for constitutional language, as if protecting the letter of the Constitution were the Court's hard but unavoidable duty. At the same time, they must also display a very serious concern for protecting state legislative sovereignty from federal encroachment. Questions of policy —of balancing interests, of deciding how useful or needful the challenged statute might be-must be rigorously put aside, typically with remarks to the effect that such questions are not properly judicial in nature, and instead the Court must display categorical respect for lines drawn in the Constitution itself. On this basis, the Court

44. Id. at 648 .

45. See, e.g., Richard A. Epstein, The Constitutional Perils of Moderation: The Case of the Boy Scouts, 74 S. CAL. L. REV. 119 (2000); Christopher W. Smart, Case Comment, The First Amendment: Expressive Association or Invidious Discrimination?-Boy Scouts of America v. Dalc, 120 S. Ct. 2446 (2000), 53 FLA. L. REV. 389 (2001).

46. Jed Rubenfeld, The First Amendment's Purpose, 53 STAN. L. REV. 767 (2001). 
must strike down federal statutes on the ground that Congress has intruded into the states' legislative territory.

Now add, however, a very different kind of holding, this time involving state statutes. Here, the Court must suddenly become textually cavalier, almost carefree. All thought of adherence to lines drawn in the constitutional text must disappear without a trace. Instead, the Court must discover an unwritten right demanding rigorous judicial scrutiny. In enforcing this unwritten right, the Court's hard but unavoidable duty will be to evaluate how useful or needful the challenged statute really is, and to this end the Court will purport to balance all the pertinent individual and state interests to determine if the statute was sufficiently justified or necessary. But above all, this unwritten right must fortuitously stop states from passing the very same kind of measures that, if passed by Congress, would be unconstitutional, because under the Court's "textualist" "federalism" cases, the pertinent legislative authority lies with the states.

\section{B. Textualism and Categorical Reasoning in the Court's Recent "Federalism" Case Law}

The present Court's "federalism" cases have all the characteristics of the first line of cases just described. Here, the Court has admirably and ostentatiously insisted that its decisions be guided by a respect for the Constitution's text. This is so not only in the Court's recent Commerce Clause holdings, but in its reasoning on Section 5 of the Fourteenth Amendment as well. A good illustration of both can be found in the Court's invalidation of the civil remedy provision of the Violence Against Women Act (VAWA), decided once again by the same five Justices. ${ }^{47}$

Violence against women, according to the Morrison majority, is not "economic in nature" and is therefore outside the reach of Congress's commerce power. ${ }^{48}$ It is also (the Court held) outside the reach of Congress's Section 5 power, which empowers Congress only to "enforce" the provisions of the Fourteenth Amendment. ${ }^{49}$ Strictly construing this word "enforce" was pivotal not only to Morrison, but to all of the Court's Section 5 case law.

Emphasizing respect for the constitutional text and the plain-meaning difference between a power to "enforce" and a power to "define" or "interpret," the Court has held since 1997 that Congress cannot under Section 5 alter the judicially interpreted meaning of the provisions of the Fourteenth Amendment. ${ }^{50}$ Instead, Section 5 allows Congress to act only in

47. United States v. Morrison, 529 U.S. 598 (2000).

48. Id. at 613 .

49. Id. at 619,627 .

50. See, e.g., City of Boeme v. Flores, 521 U.S. 507 (1997). Boeme states: 
a way calculated to redress conduct that would violate the Fourteenth Amendment as construed by the judiciary. ${ }^{51}$ In other words, Congress has no general power to create new civil rights or to prohibit discrimination beyond what would count as unconstitutional discrimination under the Fourteenth Amendment itself. And because the Fourteenth Amendment's provisions (as interpreted by the judiciary) apply only to state action, Congress has little or no power under Section 5 to reach private conduct. ${ }^{52}$

The Morrison majority made clear that it was not deciding whether VAWA was good or bad policy. Although supporters of the law marshaled copious evidence that state laws had not successfully curbed violence against women and that such violence was not only bad for women but had substantial adverse economic effects on the nation, the Court essentially held that such evidence was not germane to the constitutional issue. ${ }^{53}$ VAWA dealt with gender-based conduct and therefore arguably with a form of sex discrimination, but this was private, "noneconomic" discriminatory conduct, which under the Constitution was not a "truly national" concern, but rather a "local" matter. ${ }^{54}$ In other words, the Court rejected the idea that the constitutionality of VAWA was to be decided by balancing the pertinent interests; VAWA had to be struck down out of respect for the categorical distinctions drawn in the constitutional text (the distinction between commerce and noneconomic activity, as well as the distinction between enforcing the Fourteenth Amendment and adding to it).

Without doubt, Morrison and its predecessor cases are legally defensible. Their textualism gives them purchase, and their textual interpretations are not unreasonable. To be sure, even on their own terms, they are debatable. For example, the Court's pronouncements on the meaning of "enforce" in Section 5 of the Fourteenth Amendment seem to ignore the Court's own case law construing the very same word as it appears in the almost identical Section 2 of the Thirteenth Amendment. ${ }^{55}$

In Thirteenth Amendment cases, the Court found that the enforcement power allows Congress to define "badges of servitude" well beyond the

Congress' power under $\S 5 \ldots$ extends only to "enforc[ing]" the provisions of the Fourteenth Amendment. ... Legislation which alters the meaning of the Free Exercise Clause cannot be said to be enforcing the Clause. Congress does not enforce a constitutional right by changing what the right is. It has been given the power "to enforce," not the power to determine what constitutes a constitutional violation.

Id. at 519 (alteration in original).

51. See id.

52. Morrison, 529 U.S. at 626-27.

53. See id. at 613-14.

54. See id. at 617-18 ("We ... reject the argument that Congress may regulate noneconomic, violent criminal conduct based solely on that conduct's aggregate effect on interstate commerce. The Constitution requires a distinction between what is truly national and what is truly local.").

55. Compare U.S. ConST. amend. XIV, $\S 5$ ("The Congress shall have power to enforce, by appropriate legislation, the provisions of this article."), with id. amend. XIII, \& 2 ("Congress shall have power to enforce this article by appropriate legislation."). 
judicial construction of these terms ${ }^{56}$ Without confronting its Thirteenth Amendment case law, the Morrison Court relied instead on the Civil Rights Cases,${ }^{57}$ an 1883 decision reflecting the same constitutional premises, and the same hostile or niggardly attitude toward the Fourteenth Amendment, that produced such precedents as Plessy v. Ferguson, ${ }^{58}$ Bradwell v. Illinois, ${ }^{59}$ and the Slaughter-House Cases. ${ }^{60}$

Nevertheless, Morrison and the other decisions in this line of cases are well within the ambit of defensible legal decisionmaking. These cases can easily be read and debated as if they offered a serious effort to grapple with the proper allocation of powers between the federal and state governments under the specific grants of power found in the Constitution. Once again, I am not trying to join this debate. I am trying to ask whether we ought to be having it-whether, in other words, we can take seriously the Court's Commerce Clause and Section 5 cases as "federalism" cases. And this question comes into focus when we juxtapose these cases with the Court's "freedom of expressive association" holding in Boy Scouts v. Dale. ${ }^{61}$

\section{The Freedom of Expressive Association}

Does the freedom of association doctrine announced in Boy Scouts display the elements described above, creating the same suspect doctrinal configuration that the liberty of contract doctrine produced during the Lochner era? Obviously, Boy Scouts is but a single case, and it is too soon to know what the eventual shape of the Court's freedom of association doctrine will be. Nevertheless, Boy Scouts does reveal all three critical elements: (1) the sudden embrace of unwritten constitutional law, in stark contrast to the insistent textualism of the "federalism" cases; (2) the declaration of a judicial duty to balance interests, to decide how needful the challenged law is, in stark contrast to the "federalism" cases' categorical logic, which purports to eschew such considerations; and, above all, (3) the fortuitous conclusion that states cannot pass precisely the kind of measure that, according to the "federalism" cases, lies at the heart of state legislative prerogative. I discuss each of these propositions in turn.

56. See, e.g., Jones v. Alfred H. Mayer Co., 392 U.S. 409 (1968) (upholding a federal statute prohibiting racial discrimination in housing).

57. See Morrison, 529 U.S. at 621 (relying on and reaffirming the Civil Rights Cases, 109 U.S. 3 (1883)).

58. 163 U.S. 537 (1896) (finding that the Fourteenth Amendment protects only "civil" equality, not "social" equality, and therefore upholding a state statute segregating railway cars by race).

59. 83 U.S. (16 Wall.) 130 (1872) (upholding a state statute barring women from the practice of law).

60. 83 U.S. (16 Wall.) 36 (1872) (rendering the Privileges or Immunities Clause of the Fourteenth Amendment essentially a nullity).

61. Boy Scouts of Am. v. Dale, 530 U.S. 640 (2000). 
First, there can be no doubt that Boy Scouts displays, textually speaking, a most generous and expansive approach to constitutional meaning. The First Amendment does not make any reference to a "freedom of association," nor is that right referred to anywhere else in the Constitution. Yet there is no suggestion in the opinion that this absence of textual grounding matters.

While the "federalism" cases ostentatiously insist on a strict and narrow respect for the actual language of the Constitution, refusing to add so much as a jot to what the Constitution textually provides, there is not a hint in Boy Scouts that the particular terms of the First Amendment"speech," "press," "religion," and so on-should in any way dictate or even guide the Court's conclusion. On the contrary, Boy Scouts is as refreshingly unhampered by narrow textual considerations as were the Warren Court cases that first recognized a constitutional "freedom of association." ${ }^{62}$

It is important to see how the "freedom of expressive association" recognized in Boy Scouts not only differs from the rights expressly written into the First Amendment, but, in a critical respect, breaks out of the confines of First Amendment doctrine altogether. Imagine an ordinary case in which a person claims that an otherwise constitutional law cannot be applied to him because he wants to engage in the prohibited conduct for "expressive" reasons. Tax protesters make this kind of claim every day. Normally, this kind of claim is not thought to raise any significant free speech problems. The tax laws are not unconstitutional as applied to a tax protester. They do not become subject to strict scrutiny in such a case.

By contrast, in Boy Scouts, the Scouts were accorded a First Amendment immunity from an otherwise constitutional law. New Jersey's antidiscrimination statute, the Court held, could not be applied to the Boy Scouts without satisfying a strict scrutiny test (which, the Court went on to hold, the statute failed). Why? Because, the Court held, the Boy Scouts were not merely raising a free speech claim. They had suffered an intrusion

62. See, e.g., NAACP v. Alabama, 357 U.S. 449 (1958). One might try to explain this discrepancy by appealing to a distinction between the Constitution's "structural" provisions, which allocate powers among governmental actors, and its provisions guaranteeing individual rights. The former should be read strictly, it might be argued, the latter expansively. Whatever may be said in theory for this idea, it cannot make sense of the Court's new case law. As already discussed, the Court's "Eleventh Amendment" cases, surely examples of cases interpreting "structural" provisions, are not examples of strict construction. These cases show that the five Justices who make up the present majority are prepared to shift into textually cavalier mode-to the point of creating wholly unwritten constitutional law-in interpreting the Constitution's structural provisions too, when it suits their purposes. See, e.g., Alden v. Maine, 527 U.S. 706, 713 (1999) (acknowledging that what the Court has "sometimes referred to ... as Eleventh Amendment immunity" is "a misnomer" for a principle of state sovereign immunity "neither derive[d] from nor ... limited by the terms of the Eleventh Amendment"); see also Printz v. United States, 521 U.S. 898, 905 (1997) (striking down a federal statute on federalism grounds even though "there is no constitutional text speaking to this precise question"). 
into their associational freedom. According to the majority, when a law of general applicability does not "only" burden expression, but rather "directly and immediately affects associational rights," strict scrutiny applies. ${ }^{63}$

In the very same way, Boy Scouts makes "expressive association" claims stronger than free exercise claims. Under current doctrine, a person who challenges a generally applicable law on the ground that it burdens his religious freedom does not get a "pass" from an otherwise constitutional law; nor can he demand strict scrutiny. ${ }^{64}$ Like the freedom of speech, the free exercise of religion offers no special immunity when someone challenges a law of general applicability. By contrast, under Boy Scouts, persons who claim that their "freedom of expressive association" is burdened can demand that a law pass strict scrutiny before the law is applied to them.

Which is to say: The First Amendment doctrine created by Boy Scouts is, like the Eleventh Amendment doctrine created by Garrett, a strange one. The unwritten First Amendment "freedom of expressive association" receives greater constitutional protection than the rights actually enumerated in the First Amendment-the freedom of speech and the free exercise of religion. This oddity does not make Boy Scouts wrong. It is one factor among others to consider in thinking through the possibility that Boy Scouts should not be taken seriously as First Amendment doctrine at all.

Second, the Boy Scouts majority understands the "freedom of expressive association," as the Lochner Court understood the "liberty of contract," to demand a judicial balancing of interests in order to evaluate the needfulness of a challenged law, in pointed contrast to the categorical reasoning insisted upon in the Court's "federalism" cases. According to Boy Scouts, once plaintiffs show that a law burdens their "freedom of expressive association," a court must place these burdens on the "scales," balancing them against the state interests served by the law. ${ }^{65}$ Because New Jersey could not show or had not shown that allowing organizations like the Boy Scouts to discriminate against homosexuals would threaten compelling harms to individuals or to society, the Court held in favor of the Scouts.

The parallel to Lochner here is unmistakable. According to Lochner, once plaintiffs showed that a law burdened their "liberty of contract," a court had to engage in the very same kind of interest-balancing, scrutinizing the needfulness of the law at issue. ${ }^{66}$ In Lochner itself, for example, because

63. Boy Scouts, 530 U.S. at 659 ("Dale contends that we should apply the intermediate standard of review enunciated in United States v. O'Brien, 391 U.S. 367 (1968), to evaluate the competing interests.... But New Jersey's public accommodations law directly and immediately affects associational rights .... Thus, $O^{\prime} B$ rien is inapplicable.").

64. Employment Div. v. Smith, 494 U.S. 872 (1990).

65. See Boy Scouts, 530 U.S. at 658-59.

66. Lochner v. New York, 198 U.S. 45 (1905). 
New York had not shown that allowing bakers to work more than ten hours a day threatened substantial harms, either to bakers or to society more generally, the Court held in favor of Lochner. It was precisely this superlegislative quality of the Lochner regime-in which the Court expressly arrogated to itself the power to review legislators' judgment of how needful a particular law was-to which most objections to Lochner were directed. ${ }^{67}$

Finally, and most importantly, Boy Scouts just happens to prevent states from passing the kind of measure that, according to the Court's "federalism" cases, ought to have been a core prerogative of state legislative authority.

As noted above, a central implication of the Court's federalism cases is that Congress has no general power to define and prohibit discrimination as it sees fit. Thus, the Violence Against Women Act sought to define and remedy "gender-based" assaults as a form of sex discrimination, but because this discrimination was neither "economic in nature" nor prohibited by the Fourteenth Amendment, the statute exceeded Congress's powers. Garrett's Section 5 holding turned on the fact that the Constitution prohibits only "irrational" discrimination against the disabled, whereas the Americans with Disabilities Act requires employers to hire and accommodate disabled people even when a "rational" employer might not do so. ${ }^{68}$ The Religious Freedom Restoration Act of 1990 essentially sought to create a disparate impact antidiscrimination regime for religious observers; again the Court found that Congress had exceeded its powers, because the Act's prohibitions extended beyond the kinds of religious discrimination recognized as unconstitutional by the Supreme Court. ${ }^{69}$

If these decisions were true federalism cases, the implication would be that the power to define discriminatory conduct beyond what is directly barred by the Constitution is a power peculiarly within the prerogatives of state and local lawmakers. The implication ought to be that when state or

67. See, e.g., id. at 72 (Harlan, J., dissenting) ("What the precise facts are it may be difficult to say. It is enough for the determination of this case, and it is enough for this court to know, that the question is one about which there is room for debate and for an honest difference of opinion."); id. at 75 (Holmes, J., dissenting) ("This case is decided upon an economic theory .... If it were a question whether I agreed with that theory, I should desire to study it further . . . But I do not conceive that to be my duty, because I strongly believe that my agreement or disagreement has nothing to do with the right of a majority to embody their opinions in law.").

68. Bd. of Trs. of the Univ, of Ala. v. Garrett, 531 U.S. 356, 368 (2001); see also, e.g., Kimel v. Fla. Bd. of Regents, 528 U.S. 62, 91 (2000) (holding that a federal age discrimination statute exceeded the reach of the Fourteenth Amendment prohibition of discrimination).

69. City of Boerne v. Flores, 521 U.S. 507, 519 (1997). Needless to say, not all of the Court's new "federalism" cases have involved antidiscrimination statutes. See, e.g., Fla. Prepaid Postsecondary Educ. Expense Bd. v. Coll. Sav. Bank, 527 U.S. 627 (1999) (addressing an intellectual property statute as applied to infringement by a state actor); Printz v. United States, 521 U.S. 898 (1997) (involving a gun sale background-check statute); United States v. Lopez, 514 U.S. 549 (1995) (involving a "gun-free school zones" statute). 
local lawmakers exercise this power, the judiciary will respond with, at a minimum, considerable deference. The implication ought not to be, in other words, that when local lawmakers pass such laws, the Supreme Court will suddenly leap into a textually cavalier, superlegislative mode, finding that such laws burden an unwritten constitutional right and must therefore satisfy strict scrutiny. Yet just as the Lochner Court performed this selfcontradicting two-step through the device of the "liberty of contract," so too, Boy Scouts achieves this result through the "freedom of expressive association."

The "freedom of expressive association" recognized in Boy Scouts is a right to discriminate. Of course, judges will not describe it this way. They will refer to it as a right "not to associate," or to engage in "expressive association," or to exercise "associational freedom" (much as judges who favor reverse discrimination do not use the word "discrimination," but refer instead to "affirmative action"). But the fact remains that Boy Scouts is the first case in the modern period, and perhaps the first case in American history, to rule in favor of a party asserting a constitutional right to discriminate - at least on free speech grounds.

To be sure, the five Justices' Boy Scouts opinion concedes that the right to discriminate on expressive grounds is "not absolute." ${ }^{70}$ Instead, when a law burdens this right, it merely triggers strict scrutiny - which, as everyone knows, is almost always fatal. But how far does this right extend? In what situations does it apply? The answer given in the Boy Scouts opinion is astonishingly broad.

According to the five Justices, "freedom of expressive association" claims are not limited to associations formed to advocate or to express a particular viewpoint. "The First Amendment's protection of expressive association is not reserved for advocacy groups. But to come within its ambit, a group must engage in some form of expression, whether it be public or private." ${ }^{71}$ The Court repeats the same point later in its opinion: " $[\mathrm{A}]$ ssociations do not have to associate for the 'purpose' of disseminating a certain message in order to be entitled to the protections of the First Amendment. An association must merely engage in expressive activity that could be impaired in order to be entitled to protection." ${ }^{72}$ So long as a law "significantly affect[s]" an association's "expression," the law cannot be applied to that association unless it is the "least restrictive means" of "serv[ing] compelling state interests." 73

The Boy Scouts majority not only announced a broad view of the kinds of associations that can assert expressive association claims, but also

70. Boy Scouts, 530 U.S. at 640.

71. Id. at 648

72. Id. at 655 .

73. Id. at $640-41$. 
adopted the most expansive possible position on the kind of review applicable to an association's claim that a challenged law "significantly affect[s]" its expression. According to the Boy Scouts majority, in deciding whether a law really has a "significant" impact on an association's expression, the courts must take the association's word for it. "As we give deference to an association's assertions regarding the nature of its expression, we must also give deference to an association's view of what would impair its expression." 74

Imagine, then, an all-white homeowners' association. The homeowners seek an exemption from laws prohibiting racial discrimination. They claim that their rejection of black residents is an attempt to communicate- to one another, to their children, and to the world - the undesirability of racial mixing. As a result, antidiscrimination laws significantly impair their expression. Why aren't these homeowners entitled to the same strict scrutiny that the Boy Scouts received? The answer is: They probably are.

And why stop with nonprofit associations? Assume hypothetically that Coors, the beer manufacturer, expressly declared that it seeks to communicate sexist views about the natural roles that men and women are meant to play, that these views are central to the firm's creed (or to its marketing strategy), and that being forced to hire women "significantly affect[s]" its ability to express these views. Nothing in the Boy Scouts opinion suggests that a sex discrimination law would not have to pass strict scrutiny before it could apply to Coors in these circumstances.

The truth is that virtually every antidiscrimination law could be found to violate the "freedom of expressive association," just as the "liberty of contract" could be found to be transgressed by virtually every commercial and labor law. This is because antidiscrimination laws are nothing other than laws regulating association, and virtually every association "engage[s] in some form of expression, whether it be public or private." I do not suggest, and I do not believe, that the five Justices who decided Boy Scouts will go on to strike down core applications of Title VII any time soon. Instead, the Boy Scouts holding can be expected to be limited in a number of ways.

To begin with, distinctions among kinds of associations are likely to be made. For example, despite the contrary language in Boy Scouts, the Court (or the lower courts) may hold categorically that for-profit, commercial associations, participating in the "public" marketplace, cannot make "expressive association" claims. ${ }^{75}$ The distinction would be arbitrary, but

74. Id. at 653 .

75. Cf. Hyman v. City of Louisville, 132 F. Supp. 2d 528, 543-44 (W.D. Ky. 2001) (rejecting a Boy Scouts-like claim under "the Freedom of Association Clause of the First Amendment" where the plaintiff's "medical practice [was] simply a commercial enterprise" and where the 
not unprecedented. It would be comparable to the Lochner Court's holding that businesses " affected with a public interest" could not make "liberty of contract" claims. ${ }^{76}$

In addition, the Court can be expected to reaffirm that some or many antidiscrimination laws, in some or many contexts, serve sufficiently compelling interests to pass strict scrutiny. In this way, the Court will be able to sustain the nation's "established" antidiscrimination statutes, while allowing itself plenty of leeway to block newfangled, overly progressive definitions of discrimination-definitions that, say, protect homosexuals or push the concept of sex discrimination too far. This would be comparable to the Lochner Court's willingness to permit long-established interferences with the liberty of contract (Sunday closing laws), while striking down newfangled, too-progressive interferences, such as the minimum wage.

The result would be a loopholed, exception-ridden doctrine essentially enabling five Justices to strike down discrimination laws whenever they find them most intrusive. If this is what Boy Scouts portends-and it is hard to see how a result of this kind can now be avoided - the "freedom of expressive association" will be to antidiscrimination law exactly what the "liberty of contract" was to labor law.

The point, once again, is not that these considerations make Boy Scouts wrong. That judgment depends on what one is looking for in a Supreme Court decision. The question raised here is solely whether it makes sense to take the Court's "federalism" and "First Amendment" "freedom of expressive association" cases seriously in the doctrinal terms in which they present themselves.

On this question, the simple facts are as follows. The "federalism" battle waged by five Justices of the Supreme Court has rejected a general congressional power to define and prohibit discrimination on the ground that this power is "local," rather than "national." This battle has, moreover, proclaimed itself in the name of two things: respect for the constitutional text and respect for the prerogatives of state power. Yet in Boy Scouts, the Court struck down a state antidiscrimination measure without a hint of textual support in the Constitution.

The coincidence is sufficient to make reasonable people wonder. We need to start thinking seriously about the possibility that the Court's federalism cases should not be taken seriously as federalism cases (as efforts to allocate power between the federal and state governments). We need a new set of scholarly inquiries beyond the ones that examine the Court's constitutional cases within their conventional doctrinal boxes. This

doctor asserting a right not to hire homosexuals "made no allegation that . . . his practice ha[d] as a purpose the exercise of his religion").

76. See, e.g., German Alliance Ins. Co. v. Lewis, 233 U.S. 389, 406 (1914). 
new literature would have to ask whether the present Court's constitutional law takes its coherence and meaning from some agenda independent of considerations of constitutional text, history, doctrine, and principle. What might this agenda be?

\section{AFFIRMATIVE ACTION AND ANTI-ANTIDISCRIMINATIONISM}

According to some, the real explanation of the Court's new constitutional case law is relatively simple: The Rehnquist Court is pursuing a new form of "judicial sovereignty." 77 The great change underlying the new constitutional case law, on this view, is that the present Court no longer believes that the other "branches have equal standing to interpret the text."78 A majority harbors a "disrespect [for Congress] bordering on contempt" 79 and is not particularly sympathetic to state legislators either. This majority is determined to show that it has "a monopoly on constitutional interpretation," 80 that its judgment is supreme, that its word is exclusively authoritative.

The trouble with the "judicial sovereignty" account is that it has little explanatory power. Any case that finds anything unconstitutional can be attacked as an exercise of "judicial sovereignty." Virtually every time the Court strikes down a federal statute, the Justices implicitly assert the constitutional supremacy of their judgment, together with the view that the other "branches do not have equal standing to interpret the text." Imputing an anti-Congress animus to the present Court, or a disdain for all other political actors, while certainly consistent with every case in which the Court has struck something down, tells us little about why the Justices have struck down the particular laws they have (the number of which remains infinitesimal compared to the total amount of legislation and regulation in force). Explaining everything, the "judicial sovereignty" view explains nothing.

I explore an alternative hypothesis here. This hypothesis surrenders the all-inclusiveness of the "judicial sovereignty" view, but it may have more explanatory power. It will not apply to all of the Court's new case law, but it may as a result capture more of what is in fact going on. The hypothesis runs as follows.

A view associated with "conservatives" or "neo-conservatives" in America today holds that the "liberal" antidiscrimination movement has

77. Larry D. Kramer, The Supreme Court, 2000 Term-Foreword: We the Court, 115 HARV. L. REV. 4, 14 (2001).

78. Id.

79. Editorial, A Count Running in the Wrong Direction, N.Y. TIMES, July 6, 1995, at A20.

80. Jeremy Waldron, A Question of Judgment, TIMES LITERARY SUPPLEMENT, Sept. 28, 2001 , at 17 . 
taken a turn deeply threatening to society's fundamental values and freedoms. The perceived excesses include: the demand that Americans treat homosexuals as deserving special protection rather than condemnation; the unwarranted expansion of sexual harassment concepts; the inroads against English as a national language; the coddling of criminals and illegal aliens; the explosion of baseless Title VII litigation making it almost impossible for American businesses today to fire women or minorities; the unfair rejection of qualified whites from prestigious positions or educational opportunities in favor of undeserving minorities or women; the legitimization of same-sex marriages; and, of course, the general threat to the Western cultural canon by a new emphasis on "marginalized" voices.

These developments-real or imagined-inspire in many people an anxiety that the core premises of their society are threatened by a "radical," "politically correct," "multicultural," "special interest" antidiscrimination ideology gaining ascendancy in the "liberal media" and among intellectual elites. It is not impossible that five Justices of the Supreme Court are moved by these fears, just as five Justices appear to have been moved earlier in this century by the fear that American society was threatened by a pro-labor, redistributive ideology. If this fear were in play among the five Justices who form the currently regnant Supreme Court majority, it might find expression in a constitutional anti-antidiscrimination agenda.

This kind of anti-antidiscrimination agenda would produce the exact doctrinal effects described above. It would not set itself against "good," "traditional" antidiscrimination law, just as the Lochner majority did not oppose good, traditional limits on the liberty of contract. (I mentioned Sunday closing laws above; Holmes's other favorite example was usury.) But efforts to push antidiscrimination law beyond its "proper" sphere would be greeted with intense constitutional suspicion. Such untoward extensions would include, for example, laws banning discrimination against homosexuals, ${ }^{81}$ laws creating special causes of action for gender-based

81. See, e.g., Boy Scouts of Am. v. Dale, 530 U.S. 640 (2000). But cf. Romer v. Evans, 517 U.S. 620, 624 (1996) (striking down a state constitutional amendment forbidding any state actor to "enact, adopt or enforce any statute, regulation, ordinance or policy whereby homosexual, lesbian or bisexual orientation, conduct, practices or relationships shall ... be the basis of or entitle any person ... to have or claim any minority status, quota preferences, protected status or claim of discrimination"). If Romer is a counterexample to the anti-antidiscrimination agenda, it is not a very strong one. Romer did not hold that states could no longer criminalize homosexuality; it did not recognize homosexuality as a suspect classification; and it did not hold that homosexuality could not be a basis of discrimination in employment, in the military, or elsewhere. What Romer gave, Boy Scouts substantially takes away. Romer seems to hold that laws banning anti-gay discrimination cannot be expressly prohibited by a state's constitution; Boy Scouts holds that the very same laws can be prohibited by the Federal Constitution. Nevertheless, Romer does suggest that the anti-antidiscrimination agenda may be embraced with different strength by different Justices. (Even a judge who believes that American antidiscrimination law has gone too far need not uphold a law that "identifies persons by a single trait and then denies them protection across the board," making this class of persons "a stranger to [the] laws," which is how Justice 
violence, ${ }^{82}$ laws requiring special accommodations for the handicapped, ${ }^{83}$ and so on.

In cases striking down or limiting the scope of federal statutes that fell within this category, the Court would rely on the Commerce Clause and the language of Section 5 of the Fourteenth Amendment, stressing the Constitution's text and the prerogatives of state sovereignty. By contrast, in cases dealing with state statutes, all considerations of textualism and federalism would have to disappear because there is no textual or federalism-based support for judges who want to impose an antiantidiscrimination ideology on the states. Here the Court would be obliged to discover unwritten constitutional law to do the trick-as, apparently, it has.

In this light, the Court's affirmative action decisions also come into much sharper relief. In 1995, the Court ruled in the well-known Adarand case that all governmental measures employing a minority racial preference must be struck down unless they can satisfy "strict scrutiny." ${ }^{84}$ Since Adarand, the Court has never upheld an express racial preference, and the lower courts have, with only the rarest exception, struck down such measures across the country.

To avoid misunderstanding, I need to say it again: I am not questioning whether the Court's new color-blindness can be defended as a matter of constitutional doctrine; I am questioning whether it should be. The position that all racial classifications must pass strict scrutiny is perfectly defensible. Lots of people think that the equal protection guarantee demands no less. Adarand is without doubt a decision that can intelligently be viewed as rightly decided within the doctrinal terms in which the case presents itself.

But this was equally true of the Lochner Court's "federalism" holdings. Like a judge who always decides in favor of the plaintiff, a Supreme Court driven by an agenda independent of legal considerations would not decide every case incorrectly. A case can be rightly decided and still be, legally speaking, a joke.

This is not to say that Adarand is rightly decided. I offer no opinion on that subject here. (My views can be found elsewhere.) ${ }^{85}$ The point is only that readers who think well of Adarand's result should not reject out of hand the possibility that the inquiry pursued here could still raise significant questions about that case.

Kennedy, writing for the Court in Romer, described that case. Id. at 633,635 .) If this variation among the Justices produces occasional anomalous results, then in this respect too the antiantidiscrimination agenda is similar to the Lochner era's pro-laissez-faire agenda: It is so undertheorized jurisprudentially that exceptions and anomalies should come as no surprise.

82. See, e.g., United States v. Morrison, 529 U.S. 598 (2000).

83. See, e.g., Bd. of Trs. of the Univ. of Ala. v. Garrett, 531 U.S. 356 (2001).

84. Adarand Constructors, Inc. v. Pena, 515 U.S. 200 (1995).

85. See Jed Rubenfeld, Affirmative Action, 107 YALE L.J. 427, 433-36 (1997). 
But is it possible to evaluate whether a case should be taken seriously as constitutional doctrine other than to ask whether the case is legally defensible? Yes. The way to proceed is by asking the same questions raised in the previous Parts.

Part II, for example, described the gross disparities, logical and methodological, that appear when we juxtapose the putative textualism and categorical reasoning of Morrison with the cavalier extratextualism and balance-of-interest rhetoric of Boy Scouts v. Dale. The question, then, is whether similar gross disparities appear when we stop analyzing Adarand within its own putative doctrinal terms and instead juxtapose that case with other, relevant opinions. And if such disparities do appear, are they sufficient to suggest that Adarand might ultimately be explicable not in doctrinal terms at all, but rather in terms of the anti-antidiscrimination agenda described earlier?

There are some gross disparities on display in Adarand and its progeny, as compared with opinions by the same Justices in other contexts. To begin with, there is the question of originalism. Of the five members of the Court who have rendered most of the decisions in the Adarand line of cases (yes, the same five Justices who decided Lopez, Morrison, Garrett, Boy Scouts, Bush v. Gore, and so on), at least two have repeatedly proclaimed their fidelity to specific, original constitutional understandings. Thus Justice Thomas argued in Lopez that the Court "must further reconsider" its "Commerce Clause jurisprudence," under which Congress routinely regulates manufacturing and agriculture, because "[a]t the time the original Constitution was ratified, 'commerce' consisted of selling, buying, and bartering .... in contradistinction to productive activities such as manufacturing and agriculture." ${ }^{86}$ Similarly, Justice Scalia has advocated an originalist approach to commercial speech, ${ }^{87}$ and he has reportedly declared his opposition to the "right to die" on the ground that suicide laws were considered perfectly permissible "at the time of the drafting of the Constitution.” 88

Accordingly, given Scalia's and Thomas's categorical opposition to affirmative action, you might suppose that the Fourteenth Amendment, as originally understood, forbade minority racial preferences. At an absolute minimum, you would not think that if we looked back to the 1860 s we

86. United States v. Lopez, 514 U.S. 549, 585-86 (1995) (Thomas, J., concurring) (citations omitted).

87. See 44 Liquormart, Inc. v. Rhode Island, 517 U.S. 484, 517 (1996) (Scalia, J., concurring) (complaining about the parties' failure to discuss state legislative practices regulating commercial speech at time the First Amendment was adopted).

88. See Tony Mauro, Scalia Says There Is No Right To Die, USA TOdAY, Oct. 28, 1996, at 1 A (quoting Justice Scalia as saying, "It's absolutely plain there is no right to die," and reporting that Scalia "said his view was based on the fact that laws against suicide were universally accepted at the time of the drafting of the Constitution"). 
would find the Framers of the Fourteenth Amendment repeatedly passing laws that expressly singled out blacks for favorable treatment in the allocation of governmental benefits.

In July 1866, the Thirty-Ninth Congress-the very Congress that had just framed the Fourteenth Amendment-passed a statute appropriating money "for the relief of destitute colored women and children." ${ }^{99}$ In 1867, just as it was ramming the Fourteenth Amendment through the reconstructed Southern states, Congress passed a statute providing money for destitute "colored" persons in Washington, D.C. ${ }^{90}$ (Remember too that the Congress's relation to Washington, D.C., was in effect that of a state legislature.) And throughout the post-Civil War period, Congress adopted special procedures for awarding bounty and prize money to the "colored" soldiers and sailors of the Union Army. ${ }^{91}$

These and other, similar statutes have been featured prominently in the literature,,$^{92}$ and they could be easily found by anyone who checked the word "colored" in the index of the United States Statutes at Large. Of course, to nonoriginalists, they mean little, and even to originalists, they might not be considered proof positive, at least without further inquiry. But when Justices Thomas and Scalia, who call themselves originalists and who really do deploy originalist arguments as a privileged method of constitutional interpretation outside the field of affirmative action, simply ignore these statutes-when they refuse to acknowledge them, much less discuss them-a reasonable observer might begin to wonder whether Thomas's and Scalia's declaration that the Equal Protection Clause bars affirmative action should really be regarded as an interpretation of that Clause at all.

The issue of suddenly disappearing originalism is, however, trivial compared with certain other disparities buried behind the Adarand regime. These other disparities center on the important doctrinal shift, finally realized in that case but insufficiently discussed in the literature, from suspect classes to suspect classifications as the linchpin of strict scrutiny in equal protection law.

89. Act of July 28,1866 , ch. 296,14 Stat. 310,317 (emphasis added).

90. Resolution of Mar. 16, 1867, No. 4, 15 Stat. 20.

91. E.g., Act of Mar. 3, 1869, ch. 122, 15 Stat. 301, 302; Resolution of June 15, 1866, No. 46, 14 Stat. 357, 357-58. To these laws, one could add a number of statutes dealing with Indians. In 1865 , for example, Congress appropriated $\$ 500,000$ for the relief of "destitute Indians." Resolution of Dec. 21,1865 , No. 1, 14 Stat. 347. The standard argument purporting to distinguish Indian laws from "racial classifications" claims that a law granting privileges to members of a sovereign (or semi-sovereign) nation is not a racial classification. But this notion, if it has any force at all, has force only when Congress is dealing with Indians as members of independent "tribes" or "nations." When we cut through all the legal fictions, the 1865 statute allocating money for "destitute Indians" is just another instance of a blood-based minority preference.

92. See, e.g., Rubenfeld, supra note 85, at 430-31; Eric Schnapper, Affirmative Action and the Legislative History of the Fourteenth Amendment, 71 VA. L. REV. 753, 775, 778-80 (1985). 
When the now-familiar concept of heightened equal protection review was first expressed, the Court explained that such review might be needed when a legislature imposed special disadvantages on "discrete and insular minorities." 93 In later formulations, the term "discrete and insular minority" gave way to "suspect class," but the basic principle, repeated over and over, remained that strict scrutiny was justified only (apart from cases in which a fundamental right was implicated) when a law "operates to the peculiar disadvantage of a suspect class." 94 The term "suspect class" was never precisely defined, but the concept was clear enough (its meaning was anchored by a clear paradigm case-blacks). "Suspect classes" referred to minority groups historically treated with such prejudice and hostility that any law imposing special burdens on them, or denying them privileges granted to others, immediately triggered extreme suspicion that the same prejudice or hostility remained in play. Accordingly, the most prominent indicators of a group's "suspectness" included a history of discrimination and a relative lack of political power. ${ }^{95}$

Beyond blacks, other racial or ethnic minorities also came to be treated as "suspect classes," and women came to be treated as "semi-suspect" or "quasi-suspect." ${ }^{96}$ But in general the Court was and has continued to be extraordinarily sparing in its willingness to find that a group is suspect for equal protection purposes. When a group was found to be "nonsuspect"for example, people above the age of sixty-five-a law imposing special burdens on that group, or denying them privileges, would be examined only under the extremely lenient "mere rationality" standard and almost invariably upheld. ${ }^{97}$

Under Adarand, however, the Court no longer treats the disadvantaging of a suspect class as the trigger of strict scrutiny in race cases. Instead, the use of a "classification" is the trigger. ${ }^{98}$ That is the whole point of the color-blindness principle.

93. United States v. Carolene Prods. Co., 304 U.S. 144, 152 n.4 (1938).

94. Mass. Bd. of Ret. v. Murgia, 427 U.S. 307, 312 (1976) ("San Antonio School District v. Rodriguez, 411 U.S. 1, 16 (1973), reaffirmed that equal protection analysis requires strict scrutiny ... only when the classification ... operates to the peculiar disadvantage of a suspect class.") (emphasis added); see also Pennell v. City of San Jose, 485 U.S. 1, 14 (1987) ("As we stated in Vance v. Bradley, 440 U.S. 93 (1979), "we will not overturn [a statute that does not burden a suspect class or a fundamental interest] unless... we can... conclude that the legislature's actions were irrational.'”) (alteration in original, emphasis added).

95. See, e.g., Bowen v. Gilliard, 483 U.S. 587, 602-03 (1987) (rejecting strict scrutiny where the group burdened by the law lacked these characteristics); Lyng v. Castillo, 477 U.S. 635, 638 (1986) (rejecting heightened scrutiny because close relatives are not a suspect class).

96. See, e.g., City of Cleburne v. Cleburne Living Ctr., 473 U.S. 432, 440-41 (1985) (stating that strict scrutiny applies to distinctions based on race, alienage, or national origin, and a heightened standard of review applies to legislative classifications based on gender).

97. E.g., Murgia, 427 U.S. at 312-14.

98. Adarand Constructors, Inc. v. Pena, 515 U.S. 200, 227 (1995) (emphasis added). 
There is nothing inherently incoherent or indefensible about shifting the focus of equal protection law from suspect classes to suspect classifications in this way. The shift is so natural, within the doctrinal terms in which Adarand presents itself, that most people do not even notice it. Its peculiarity emerges only when the Adarand regime is situated within the larger body of equal protection case law.

The peculiarity is as follows. Nearly everywhere else in equal protection law, it continues to be the case that groups failing to meet the traditional criteria of suspectness do not get to take advantage of strict scrutiny. If rich people bring an equal protection challenge against a law providing special benefits to the poor, a judge would dismiss out of hand the claim that the law "discriminates" against the rich and must therefore be subjected to strict scrutiny. The rich may be a numerical minority, but they are far from politically powerless, and they have not been the victims of a history of exclusion, denial of opportunities, subjugation, or any other kind of discrimination comparable to that suffered by blacks or women. On this ground, the judge would easily conclude that the rich are not a suspect (or even "semi-suspect") class, and that a welfare law need only pass rational-basis review. ${ }^{99}$

This conclusion would represent perfectly standard equal protection reasoning. There is nothing odd about it; it makes good sense. What is odd is the combination of this standard equal protection reasoning within the Adarand regime.

Under Adarand, if whites bring an equal protection challenge against a law employing a racial preference in the allocation of a governmental benefit, a court will apply strict scrutiny-even though whites are not a minority, are not powerless, and have suffered no history of discrimination. Adarand essentially treats whites as if they were a suspect class, even though this result would violate everything the Court has ever said about the types of groups that qualify for suspect class status. Neither in Adarand nor in any subsequent case has the Court offered a word of explanation as to why, of all the groups not meeting the criteria of a suspect class, whites alone should be entitled to strict scrutiny when a law does not include them in the allocation of governmental benefits.

99. See, e.g., United States v. Hirschberg, 988 F.2d 1509 (7th Cir. 1993). The following passage is especially illustrative:

At oral argument, the defense stated that the wealthy are a suspect class and suffer greater prejudice than do racial minorities, a fact "born[e] out by scores of cases." We expressed our skepticism, but were assured that "legions of cases" recognize this class prejudice, and those cases were "set forth and discussed at length in the brief." Try as we might, we find no cases in the defendant's brief or in our research that identify the wealthy as a suspect class.

Id. at 1514-15. 
The consequence is not only an advantaging of whites, but a disadvantaging of blacks. Under Adarand, blacks and other racial or ethnic minorities are denied a legal privilege enjoyed by just about every other minority in the country.

Farmers can be given special governmental benefits. Large corporations can. Riparian landowners can. Victims of environmental damage can. Poor people, veterans, disabled people, railroad workers, ophthalmologists- just about any minority group can be singled out by law for special advantages in the allocation of governmental benefits or opportunities without running afoul of the Equal Protection Clause. But blacks cannot.

If a state university wanted to give a special admissions preference to farmers or their children, it could do so without fear of encountering any strict judicial scrutiny. If a legislature wanted to give a special eligibility preference to veterans or to small businesses in a governmental licensing or contracting program, it would have complete constitutional discretion to do so, provided only that a "rational basis" existed. But let these state actors dare to give a preference to blacks, and the Fourteenth Amendment will suddenly rise up as a bar to their plans.

This peculiar feature of Adarand does not jump out, as it were, from the internal logic of that case or from anything the present majority of the Court has said in Adarand or its progeny. Only by situating Adarand within the rest of equal protection jurisprudence can one recognize the extent to which the doctrine of color-blindness actually denies to racial minorities a privilege enjoyed by virtually every other minority group in the political system.

Color-blindness guarantees that a state's treatment of blacks is no different, formally speaking, from its treatment of whites. That is its point. And that is its virtue, in the eyes of its supporters.

But color-blindness also guarantees-formally and substantively-that the government's treatment of blacks (and other racial minorities) must be worse than its treatment of virtually every other minority group in the nation, in the specific sense that while virtually every other minority can be singled out for preferential treatment in the allocation of public benefits or opportunities, blacks cannot. In this light, Congress's preferential "colored" laws of the 1860s begin to make more sense. By making special provisions for "colored" persons, Congressmen in the 1860s did no more for blacks than they had done and would do for numerous other minority groups perceived to need or to deserve federal assistance. Their implicit understanding was that guaranteeing blacks the equal protection of the laws (or the privileges and immunities of citizens) did not somehow mean blacks were to lose a privilege enjoyed by virtually every other group in the nation.

Everyone knows that the Equal Protection Clause was designed above all to ensure equal protection for blacks. The denial to black Americans, as 
a group, of legal rights or privileges enjoyed by any other group is the paradigmatic Fourteenth Amendment violation. Is this basic fact about the Fourteenth Amendment's meaning really reconcilable with a regime in which, alone out of almost every minority group in the country, blacks (and other racial minorities) are denied an important legal privilege-the privilege of being able to be singled out by law for specially favorable treatment in the allocation of governmental benefits or opportunities? How, then, can Adarand be taken seriously as a doctrinal elaboration of the Equal Protection Clause when it denies to blacks a privilege of legal protection enjoyed by so many other groups?

Two objections will occur to most of us when we first encounter this disturbing line of thought.

The first objection runs as follows. There is an analytical error in saying that, as a result of Adarand, racial minorities are legally worse off than the poor, the handicapped, veterans, or other minority groups who can constitutionally receive preferential treatment. Color-blind strict scrutiny is not just a sword, striking down laws advantaging racial minorities. It is also a shield, protecting them from being legally disadvantaged. By contrast, the "mere rationality" test leaves other minority groups without significant protection from laws disadvantaging them. So it is a question of taking the bitter with the sweet. Under Adarand, racial and ethnic minorities can be neither specially advantaged nor disadvantaged, whereas other minorities can be both specially advantaged and disadvantaged. Possibly blacks are worse off in one respect, but they are better off in another.

If the premise of this objection were correct, it would raise a tricky question. According to the objection, the fact that, in one respect, the Adarand doctrine discriminates on its face against blacks and other racial minorities (as compared to virtually all other minorities) is offset by the fact that it privileges them in another. If this were so, the question would be whether this unequal treatment-sometimes advantageous, sometimes disadvantageous-comported with the equal protection of the laws.

But the objection is not correct. The truth is that groups such as the poor, the handicapped, and veterans get the best of both constitutional worlds, while blacks and other racial minorities do not.

Take the poor. Obviously, the poor can constitutionally receive specially favorable treatment in the allocation of governmental benefits and opportunities. It happens all the time. A law reserving certain housing units for low-income individuals, or giving a preference at a state university for students from families with low incomes, is perfectly constitutional. So in this respect the poor enjoy a legal privilege that blacks do not.

But now imagine a law that on its face excluded people with low incomes from certain housing units (even if some of the excluded people had money available to pay the rent) or imposed a quota at a state university 
on the total number of students admissible from low-income families (even if some of the excluded students had money available to pay tuition). Does anyone think that a court would uphold this law?

Observe that these laws would easily satisfy "mere rationality" review because there is always a "rational relationship" between higher income and ability to pay. In other words, if we are confident that a court would strike down this kind of law, it is because we understand that courts would in fact review such legislation with a much more biting scrutiny than the "mere rationality" test might be thought to imply. As a matter of fact, while it is easy to imagine constitutional statutes that privilege the poor, it is very difficult to imagine a statute (1) that on its face denies poor people any legal right, privilege, or opportunity afforded to the better off, and (2) that would be upheld in court. Which is to say: Poor people enjoy the privilege of receiving preferential treatment throughout the legal system, and they also enjoy protection from laws that discriminate against them. ${ }^{100}$

The same is true of people with disabilities. They receive special accommodations under a variety of laws, and despite the "mere rationality" standard, they are also constitutionally protected from laws that discriminate against them on the basis of hostility or prejudice. ${ }^{101}$ The truth is that throughout equal protection jurisprudence, nonracial minority groups that are plausibly thought of as the targets of invidious discriminatory animus enjoy both the privileges of preferential treatment and a protection against discrimination.

Veterans offer another kind of example. They can and do receive preferential treatment of various kinds. But imagine a state legislature suddenly deciding to penalize veterans in some way, passing a law that singled them out on its face and excluded them from benefits, rights, or opportunities offered to others. Such a law would almost certainly be struck down. At a minimum, it would be subjected to extremely rigorous judicial scrutiny.

Thus the premise behind the first objection is wrong. The Adarand regime does disfavor blacks and other racial minorities as compared to many other minority groups, who are not only protected against discrimination but can still receive preferential treatment. Surprising as it may be, the present majority of the Supreme Court essentially uses the

100. Laws favoring the poor are routine in our system, but laws facially discriminating against the poor are, of course, rare. In 1941, the Court faced such a law and struck it down. See Edwards v. California, 314 U.S. 160 (1941) (invalidating a California statute barring nonresident indigents from being brought into the state). Justice Jackson urged the Court in that case to "say now, and in no uncertain terms, that a man's... being without funds is a neutral factconstitutionally an irrelevance, like race, creed, or color." Id. at 184-85 (Jackson, J., concurring).

101. See, e.g., City of Cleburne, 473 U.S. at 432 (striking down on equal protection grounds an ordinance requiring a special permit for the construction of a home for the mentally handicapped). 
Constitution's phrase "the equal protection of the laws" to force states to deny blacks (and other racial minorities) a legal right enjoyed by many other minority groups.

I said, however, that there were two objections to this disturbing conclusion. The second objection acknowledges that Adarand disfavors racial minorities in this way, but offers a strong argument in defense of this result. On this view, racial classifications are distinguishahle from virtually all other classifications; even when such classifications favor blacks, they are properly treated much more suspiciously than the preferential treatment that other groups can and do receive. The argument runs as follows.

Racial preferences, however well-intended, have poisonous consequences for the very minority groups they are intended to benefit. Affirmative action has the tendency to foster invidious racial stereotypes; that is why even "benign" racial classifications must be subject to strict scrutiny. Thus, it is quite unfair and illogical to think of Adarand as injurious to the rights or interests of racial minorities. Yes, Adarand prevents racial minorities-alone out of almost every minority group in the country-from receiving preferential treatment, but it does so for their own good, and as a result it does so for good constitutional reasons. The argument, then, is that strict scrutiny of affirmative action plans is necessary because of affirmative action's pernicious (although unintended) consequences for racial minorities.

This proposition is in fact the principal argument repeatedly invoked by the Justices who have joined and defended the Adarand regime. For example: " $[R]$ acial paternalism and its unintended consequences can be as poisonous and pernicious as any other form of discrimination. So-called 'benign' discrimination teaches many that because of chronic and apparently immutable handicaps, minorities cannot compete with them without their patronizing indulgence." 102 Or again: "[W]e subject racial classifications to strict scrutiny precisely because that scrutiny is necessary to determine whether they are benign ... or whether they misuse race and foster harmful and divisive stereotypes without a compelling justification." ${ }^{103}$ Or again: "Unless [racial classifications] are strictly reserved for remedial settings, they may in fact promote notions of racial inferiority and lead to a politics of racial hostility." 104

102. Adarand, 515 U.S. at 241 (Thomas, J., concurring).

103. Bush v. Vera, 517 U.S. 952,984 (1996) (plurality opinion of O'Connor, J., joined by Rehnquist, C.J., and Kennedy, J.).

104. City of Richmond v. J.A. Croson Co., 488 U.S. 469, 493 (1989) (plurality opinion); see also Adarand, 515 U.S. at 229 (quoting Fullilove v. Klutznick, 448 U.S. 448,545 (1980) (Stevens, J., dissenting) (" $[\mathrm{A}]$ statute of this kind inevitably is perceived by many as resting on an assumption that those who are granted this special preference are less qualified.... [T] hat perception ... can only exacerbate rather than reduce racial prejudice ...."). 
The idea that affirmative action fosters racist stereotypes and, as a result, does more harm than good to racial minorities is without doubt a plausible basis for supporting the Adarand result. From this point of view, the present majority of the Supreme Court is not denying blacks equal protection when it imposes strict scrutiny on every governmental effort to grant them preferential treatment. On the contrary, because preferential treatment has such potentially pernicious consequences for minorities, the Adarand regime protects blacks, and in doing so it responds to one of the fundamental goals behind the Equal Protection Clause-blocking the legalized perpetuation of racist stereotypes.

But the truth is that we can take this argument seriously only if we forget to juxtapose Adarand with other lines of cases. Again the relevant analogy is to the Lochner Court's "federalism" arguments, which could be taken seriously as federalism cases only so long as one failed to notice that, in many other cases, the Lochner Court demonstrated that it had no more intention of permitting states to regulate labor than it had of permitting Congress to do so. If we accept the proposition that affirmative action is subject to strict scrutiny because of its potential harm to minorities, we credulously imagine that Adarand stands for something like the following principle: Even when "benignly" intended, state action is properly subject to strict scrutiny if it poses a very substantial risk of fostering racist stereotypes or otherwise causing significant harms to racial minorities.

But the moment we juxtapose Adarand with other lines of equal protection case law, we see that Adarand does not really stand for this principle at all. The five Justices who have decided most of the new colorblindness cases do not support this principle. They do not and will not apply it outside the domain of racial preferences.

The five Justices who decided Adarand have no intention of overturning Washington $v$. Davis, ${ }^{105}$ which holds that inadvertent racial harms are not enough to trigger strict scrutiny. I think Davis is correct, so I am not arguing that the Court should overrule that case. But so long as the five Justices remain committed to it, we cannot take seriously their repeated proclamations that strict scrutiny for affirmative action is necessary and proper because affirmative action inadvertently harms minorities.

Just think of standardized tests in the university setting. Everyone understands that Adarand does not call into question governmental use of standardized tests. On the contrary, the clear message of Adarand is that if a state university relied exclusively on standardized tests for its admissions decisions, there would be no constitutional problem.

105. 426 U.S. 229 (1976) (rejecting an equal protection challenge to the use of a standardized test in hiring decisions, where blacks performed disproportionately worse on the test, but where there was no allegation that the test had been adopted because of its propensity to exclude blacks). 
But standardized tests plainly have the (unintended) effect of promoting racist stereotypes. Indeed they have this effect to a much greater extent than does affirmative action. The repeated and well-publicized disparities among different racial groups in their test scores have probably done more to promote invidious stereotypes of black inability in the United States than affirmative action could ever be charged with having done. These disparate scores not only foster popular stereotypes about differing racial abilities; they are actually used by respected social scientists in an effort to prove differing racial abilities. ${ }^{106}$ If, in Justice Thomas's words, affirmative action "teaches many" 107 that blacks are less able, and if as a result affirmative action must be constitutionally barred unless it can pass the nearly always fatal strict scrutiny standard, then standardized tests ought to be equally barred, because they prove or confirm, in many people's eyes, what affirmative action merely "teaches."

But of course the five Justices who produced Adarand have no intention of barring the use of standardized tests, or subjecting them to strict scrutiny, because of the harms they inadvertently inflict on minorities. Standardized tests are racially neutral on their face. The Adarand result therefore does not obtain.

But this means that the Adarand result cannot be defended in terms of the proposition stated above, which underlies so much of the present majority's rhetoric: the proposition that affirmative action (or, more generally, the use of racial classifications) deserves strict constitutional scrutiny because it has the unintended effect of fostering invidious racist stereotypes and otherwise harming minorities. Adarand announces its change in constitutional doctrine in terms of this proposition, but the truth is that this proposition is irreconcilable with other constitutional results to which the majority is committed. For good or ill, the doctrinal terms in which the current Supreme Court majority presents its conclusions in Adarand cannot be taken seriously.

To summarize: There are two basic defenses of Adarand; each is perfectly intelligible in its own terms, but each becomes much less intelligible when juxtaposed with other important equal protection doctrines. First, strict scrutiny for race-based affirmative action can be defended on the ground that affirmative action intentionally disadvantages whites. But this defense of Adarand in effect treats whites as a suspect class, a result contradicting everything the Court has ever said about the criteria required to make a group "suspect" for equal protection purposes.

106. See, e.g., Richard J. HerRnstein \& Charles Murray, The Bell CuRve: INTELLIGENCE AND CLASS STRUCTURE IN AMERICAN LIFE (1994).

107. Adarand, 515 U.S. at 241 (Thomas, J., concurring). 
Second, strict scrutiny for race-based affirmative action can be defended on the ground that affirmative action unintentionally harms blacks (and other racial minorities) by promoting invidious racial stereotypes. But this effects-based defense of Adarand is very hard to reconcile with the Washington v. Davis doctrine. Under Davis, the Justices will say clearly and emphatically that harms to minorities, including the promotion of invidious racial stereotypes, are insufficient to trigger strict scrutiny unless these consequences were intended. Under Adarand, the Justices will say clearly and emphatically that the promotion of invidious racial stereotypes demands the application of strict scrutiny, even though this consequence was unintended. To be sure, the Justices will add that this rule applies only to laws employing racial classifications, thus assuring a superficial consistency with Davis. But if the racial classifications in an affirmative action program demand strict scrutiny because of their unintended promotion of invidious racial stereotypes, then Davis's categorical denial of strict scrutiny to benignly intended race-neutral measures no longer makes sense. On the contrary, strict scrutiny ought equally to apply to measures like standardized tests, which, even though they do not employ a racial classification as affirmative action does, nevertheless promote invidious racial stereotypes to an extent at least as great, if not far greater.

Striving to take Adarand seriously on its own terms, we may see it as an effort to ensure the most rigorous judicial scrutiny of governmental action that runs a high risk of (inadvertently) promoting invidious racial stereotypes. The five Justices who decided Adarand explicitly defend their ruling in these terms. But given these Justices' simultaneous adherence to Davis, which refuses strict scrutiny for governmental action that demonstrably (but inadvertently) promotes invidious racial stereotypes, their statements should not be credited. We need to understand Adarand in different terms.

Adarand becomes perfectly straightforward when viewed as part of a broader commitment to strike down the felt excesses of contemporary antidiscrimination ideology. The civil rights movement of the 1960s (it is usually said) insisted on racial equality before the law. So far, none of the Justices has called that ideal into question. But assume that five Justices believe that the antidiscrimination "zealots" of later decades went beyond this acceptable goal. Rejecting all-American values of color-blindness, sexblindness, and meritocracy, these antidiscrimination zealots have pursued racial preferences, gender preferences, sexual orientation neutrality, and so on. They want equality of outcomes, not equality of opportunity; they want to legislate a pro-homosexual morality, not prohibit invidious discrimination.

For better or worse, this line of thinking appears to represent the simple, unvarnished reality behind Adarand (and Boy Scouts) far better than 
the Justices' own doctrinal reasoning. Such are the terms in which Adarand should be understood.

It is time to recognize this truth and to stop taking seriously the idea that Adarand is profitably debated in terms of constitutional methodology (such as originalism) or constitutional principle (such as the principle that affirmative action must be strictly scrutinized because it threatens to foster invidious racial stereotypes or otherwise harm minorities). The Adarand regime could be a perfectly serious regime of constitutional methodology and principle, but only if other major components of equal protection law were changed profoundly in ways that the present Justices would not accept. Until such changes are made, it does not seem possible or sensible to take Adarand seriously in its own doctrinal terms.

\section{CONCLUSION}

For a brief historical moment, a shadow overhung constitutional lawthe shadow of Bush v. Gore. ${ }^{108}$ Many people consider the five-Justice majority opinion in that case to have been, legally speaking, a kind of joke. Obviously, those who hold this view wonder whether that case may be the proverbial thirteenth chime of the clock, not only wrong in itself, but calling into question what came before.

But I have avoided all discussion of that case here, forgoing any advantage such a discussion might have given to the argument. Bush $v$. Gore is a singular point in a number of respects, and its shadow has already dissipated to a considerable extent. The aim of this Essay was instead to look at a set of "ordinary" cases that, when viewed in their own doctrinal categories, look perfectly plausible, but when viewed as a whole, juxtaposed across doctrines, begin to look suspicious. If this suspicion proves well-founded, it will mean that the current Court's constitutional case law has to be understood less in terms of its ostensible doctrinal reasoning, and more in terms of an underlying agenda, founded on a deeply held but as yet poorly theorized sense that antidiscrimination law in this country has taken a very wrong turn.

If all this is true, the right response might not be to jettison the Court's case law, but to jettison the whole enterprise of taking constitutional doctrine seriously. After all, constitutional law is always driven by one agenda or another. Perhaps the sun set long ago on law's empire; perhaps now is a propitious time finally to put an end to the nonsense about the foundations that "We the People" laid down a century or two ago. Perhaps instead the only kind of question really worth asking is whether the agenda

108. 531 U.S. 98 (2000). 
pursued by a particular Court is, for example, legitimated by recent popular elections, or whether it makes the Constitution the best it can be. 